\title{
Genetic parameters of linearly scored conformation traits of Polish Black-and-White cows ${ }^{*}$
}

\author{
A. Żarnecki' ${ }^{1}$ M. Morek-Kopeć and W. Jagusiak \\ Kraków Agricultural University, Department of Genetics and Animal Breeding \\ Al. Mickiewicza 24/28, 30-059 Kraków, Poland
}

(Received 20 May 2003; accepted 28 October 2003)

\begin{abstract}
Type classification records of 87,352 Black-and-White cows collected between 1995 and 2000 were analysed. The linear evaluation system included 15 traits scored from 1 to 9 , height measured at rump, and the final score made of four breakdown traits. Linearly scored traits varied much more than the remaining traits, ranging from $15.7 \%$ for body depth to $22.7 \%$ for central ligament. The mean scores for teat length and fore teat placement were much lower than the scores for muscularity, dairy character and chest width. The phenotypic correlations between traits were, in general, smaller than the genetic correlations. Highest heritability was obtained for height measure at rump (0.463). Heritabilities of breakdown traits were high to moderate. The highest was heritability of size $(0.416)$. Heritability of final score reached almost 0.30 , slightly lower (0.291) was heritability of conformation and dairy character, and the lowest was heritability of udder and legs. Heritabilities of linear scores of 9 traits ranged between 0.204 and 0.301 , of the four traits between 0.1 to 0.2 , and in foot angle was only 0.074 . The final score was genetically correlated with its component traits, especially with conformation and dairy character $(0.850)$. Dairy character was correlated with body depth and chest width. Some of the udder traits were genetically correlated, especially udder height with udder width and central ligament with rear udder height and udder depth. The estimated parameters indicate that some conformation traits possibly can be improved.
\end{abstract}

KEY WORDS: heritabilities, genetic correlation, conformation, linear scores

\section{INTRODUCTION}

In the last twenty years, descriptive evaluation of conformation traits has been replaced by the linear scoring system in many countries. In the first stages of implementation the new system, genetic and environmental effects were studied (Thompson et al., 1983; Lucas et al., 1984; Foster et al., 1989). Estimates of heritabilities of linearly scored type traits were similar in magnitude to the

\footnotetext{
${ }^{*}$ Supported by the State Committee for Scientific Research, Grant No. 5 P06D 01015

${ }^{1}$ Corresponding author: e-mail: rzzarnec@cyf-kr.edu.pl
} 
heritabilities of milk production traits (Thompson et al., 1983; Schaeffer et al., 1985; Misztal el al., 1992; Short and Lawlor, 1992; Ducrocq, 1993). Effects of parity, age at calving and stage of lactation are considered the major environmental factors (Hayes and Mao, 1987; Funk et al., 1991), so these effects are included in breeding value evaluation models, or else adjustment factors for these effects are used. BLUP-multitrait or single trait models also include effects of herd, yearseason of calving, classifier, and some significant interaction effects (Lucas et al., 1984; Hayes and Mao, 1987; Funk et al., 1991).

A linearised scoring system of conformation traits was introduced in Poland in 1995, and three years later a preliminary genetic evaluation was made (Żarnecki et al., 2000).

The objective of this study was to estimate the genetic parameters of linearly scored type traits of Polish Black-and-White cattle.

\section{MATERIAL AND METHODS}

Data were type classification records of Black-and-White cows collected between 1995 and 2000. Cows were evaluated between day 15 and 180 of first lactation by 17 trained classifiers. The linear evaluation system included 15 traits scored from 1 to 9 (Table 1), height measured at rump, and the final score made of four breakdown traits (Table 2). Sires with less than 10 daughters and herd-year-season of calving-classifier subclasses with less than 5 cows were removed from the file. Only cows with known sires that calved between 18 and 45 months of age and were evaluated between 15 to 180 days in milk were included. After final edits, records of 87,352 cows in 6557 herd-year-season of calving-classifier subclasses were available for analysis. Stage of lactation at appraisal was obtained by dividing days since first calving into 11 fifteenday periods. Age at calving (in months) was divided into 5 following categories:

1. $18-23$

2. $24-29$

3. $30-35$

4. $36-41$

5. $42-45$

Genetic groups were defined according to the percentage of Holstein-Friesian genes:

Group $1-0$

Group $2-(0,25>$

Group $3-(25,50>$

Group $4-(50,75>$

Group 5 - $(75,87.5>$

Group $6-(87.5,100)$ 
TABLE 1

Definition of linear type traits

\begin{tabular}{lll}
\hline \multirow{2}{*}{ Trait } & \multicolumn{1}{c}{ Extreme scores } \\
\cline { 2 - 3 } & \multicolumn{1}{c}{1} & \multicolumn{1}{c}{9} \\
\hline Body depth & shallow & deep \\
Chest width & narrow & wide \\
Rump angle & high pins & low pins \\
Rump width & narrow & wide \\
Rear leg set & posty & sickled \\
Foot angle & low & steep \\
Fore udder attachment & loose & tight \\
Rear udder height & very low & very high \\
Central ligament & broken & strong \\
Udder depth & shallow & deep \\
Rear udder width & narrow & wide \\
Fore teat placement & close (teat side) & apart \\
Teat length & short & long \\
Muscularity & convex & flat \\
Dairy character & coarse & angular \\
\hline
\end{tabular}

TABLE 2

Definition of general characteristics traits

\begin{tabular}{lll}
\hline Trait & \multicolumn{2}{c}{ Extreme scores } \\
\hline Size, 1-15 & small & tall \\
Conformation and dairy character, 1-15 & undesired & desired \\
Legs and feet, 1-20 & undesired & desired \\
Udder, 1-50 & undesired & desired \\
Final score, 1-100 & undesired & desired \\
\hline
\end{tabular}

(Co)variance components were estimated by the MTCAFS (MTC) multitrait REML program (Misztal, 1994) and heritabilities and genetic correlations were calculated. This program utilizes the Expectation-Maximization algorithm and canonical transformation.

Following linear model was used:

$\mathbf{y}$ is a vector of observations

$$
\mathbf{y}=\mathbf{X b}+\mathbf{Z u}+\mathbf{e}
$$

b is a vector of fixed effects (herd-year-season of calving-classifier, stage of lactation, genetic group and age class)

$\mathbf{u}$ is a vector of random animal effects

e is a vector of random error

$\mathbf{X}, \mathbf{Z}$ are coincidence matrices. 
Expectations and (co)variances were:

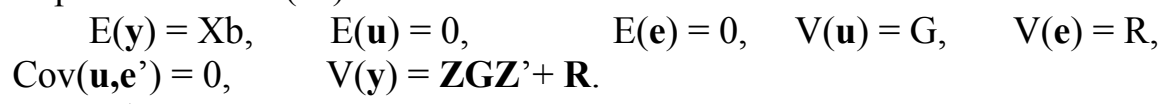

$\mathbf{G}=\mathbf{A}^{-1} \otimes \mathbf{G}_{\mathbf{0}}$ where

$\mathbf{A}^{-1}$ is a numerator relationship matrix

$\mathbf{G}_{\mathbf{0}}$ is a genetic (co)variance matrix between traits

$\mathbf{R}=\mathbf{I} \otimes \mathbf{R}_{\mathbf{0}}$ where

$\mathbf{R}_{\mathbf{0}}$ is a residual (co)variance matrix between traits

$\otimes$ denotes the Kronecker product

Twenty traits were considered simultaneously. Parameters for the final score, because it is a sum of breakdown trait scores, were calculated in separate runs with all other traits.

Computations were performed on an SGI 2800 computer with 40 GB memory at the Academic Computing Centre CYFRONET AGH. The required convergence was reached after 72 iterations.

\section{RESULTS}

Characteristics of data are shown in Table 3. The only measurements - height at rump and final score with its four breakdown traits, were characterized by the lowest coefficient of variation. Linearly scored traits displayed much larger variation, ranging from $15.7 \%$ for body depth to $22.7 \%$ for central ligament. The mean scores for teat length and fore teat placement were much lower than the scores for muscularity, dairy character and chest width. The differences reached about 1.5 points.

The phenotypic correlations between traits (Table 4) were, in general, smaller than the genetic correlations. The final score, composed of four breakdown traits, was highly correlated with these traits and many linearly scored traits. Especially high were the correlations of the final score with height at rump (0.754), foot angle (0.424), rear udder height (0.494), udder width (0.482), muscularity $(0.532)$ and dairy characteristics $(0.831)$. The latter trait was also highly correlated with several breakdown traits.

Heritabilities of breakdown traits were high to moderate (Table 4). The highest was heritability of size (0.416). Heritability of final score was almost 0.3 ; heritability of conformation and dairy character was slightly lower $(0.291)$ and the lowest was heritability of udder and legs. High heritability $(0.463)$ was obtained for the only measured trait height at rump. Heritabilities of linear scores for 9 traits ranged between 0.2 and 0.3 , for four traits between 0.1 and 0.2 , and for foot angle was only 0.074 . 
TABLE 3

Means, standard deviations (SD) and coefficients of variation of type traits of $87352 \mathrm{BW}$ cows

\begin{tabular}{lrcc}
\hline Trait & Mean & SD & CV, \% \\
\hline Size & 11.05 & 1.42 & 12.9 \\
Conformation and dairy character & 11.08 & 1.10 & 9.9 \\
Legs and feet & 15.39 & 0.90 & 5.8 \\
Udder & 39.37 & 2.61 & 6.6 \\
Final score & 76.89 & 4.41 & 5.7 \\
Height measure in rump & 136.83 & 4.56 & 3.3 \\
Body depth & 6.44 & 1.01 & 15.7 \\
Chest width & 5.52 & 1.11 & 20.1 \\
Rump angle & 5.29 & 1.00 & 18.9 \\
Rump width & 5.69 & 1.08 & 19.0 \\
Rear leg set & 5.45 & 0.88 & 16.1 \\
Foot angle & 5.14 & 1.09 & 21.2 \\
Fore udder attachment & 6.09 & 1.12 & 18.4 \\
Rear udder height & 5.84 & 1.06 & 18.2 \\
Central ligament & 5.86 & 1.33 & 22.7 \\
Udder depth & 6.06 & 1.26 & 20.8 \\
Rear udder width & 5.57 & 1.19 & 21.4 \\
Fore teat placement & 4.73 & 1.00 & 21.1 \\
Teat length & 4.76 & 1.02 & 21.4 \\
Muscularity & 6.62 & 0.98 & 14.8 \\
Dairy character & 6.32 & 1.02 & 16.1 \\
\hline
\end{tabular}

Genetic correlations appear above diagonal in Table 4. Similar to the phenotypic correlations, the final score was genetically correlated with its component traits, especially conformation and dairy character (0.850). Dairy character was correlated with body depth and chest width. Some of the udder traits were genetically correlated: udder height with udder width, and central ligament with rear udder height and udder depth.

\section{DISCUSSION}

Means of linearly scored type traits indicate the biological extreme toward which the analysed population tends. Unlike breakdown traits and final score, linear scores do not reflect the desirability of a trait. Means of linear traits ranged from 4.73 for fore teat placement to 6.62 for muscularity. A difference of almost 2 points between means is not unusual; similar ranges were found by other authors (Ducrocq, 1993). The variation of the breakdown traits and final score was small, while the linear traits displayed much larger coefficients of variation. The largest variation was found for central ligament (22.7\%), the smallest for muscularity (14.8\%) rear leg set and dairy character (16.1\%). Large variation 
壳

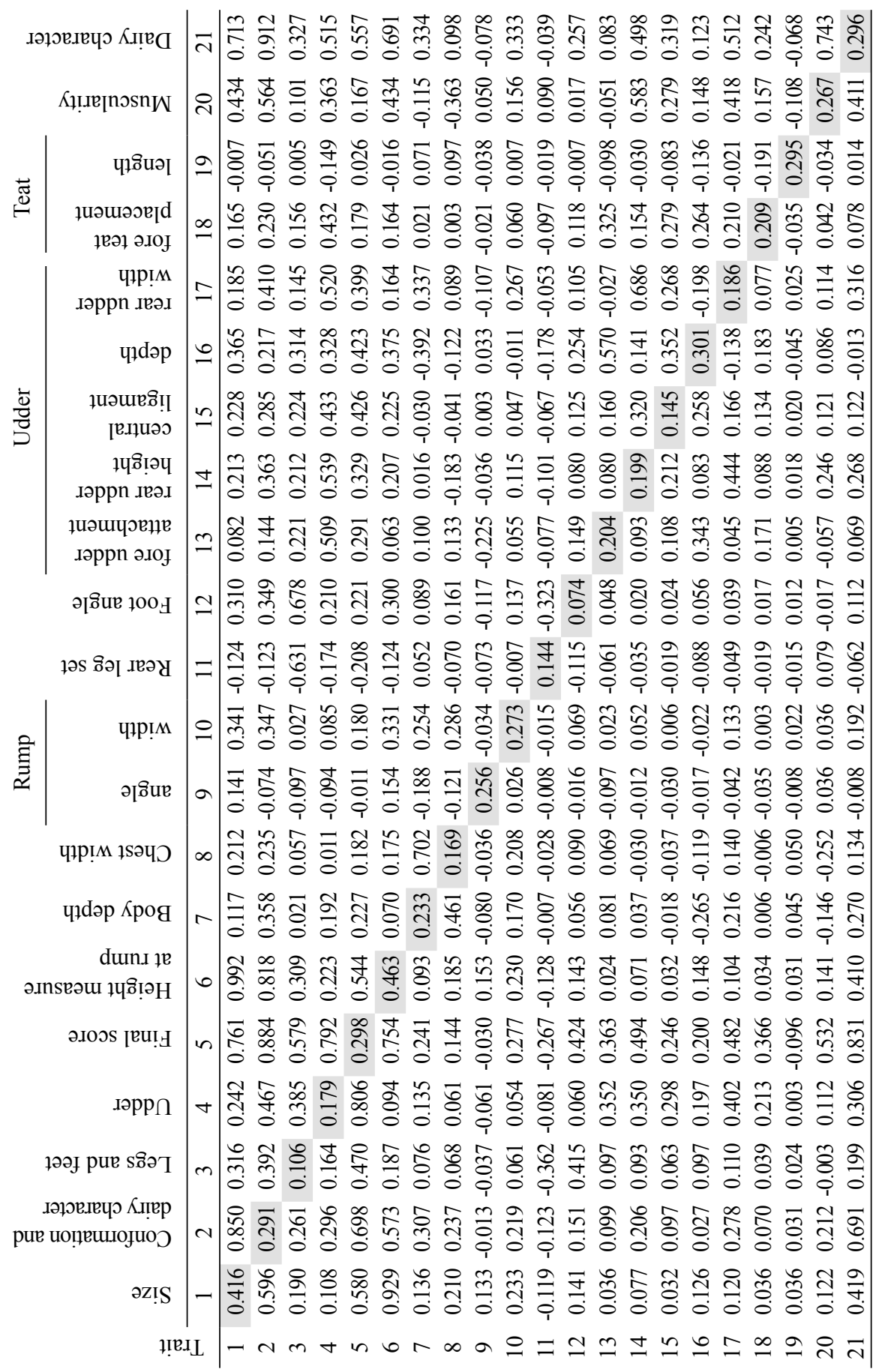


for central ligament or udder cleft has been reported in other studies (Short and Lawlor, 1992; Ducrocq, 1993). In general, the variation of linear traits in our studies does not show any particular pattern and seems to be in agreement with other research.

Heritabilities of breakdown traits, final score and linear traits related to body size were medium to high. Estimates of most of linear traits ranged from 0.145 to 0.301 . This range is similar to one used by INTERBULL member countries in their genetic evaluation of conformation traits (INTERBULL, 2001). Heritabilities of most traits are large enough to ensure at least small genetic changes from selection, but as pointed out by Foster et al. (1989), a change in scores is not necessarily associated with improvement of the traits.

Phenotypic correlations ranging from 0.141 to 0.185 (Table 4 ) showed that taller cows had higher scores for chest width, foot angle, udder depth and muscularity. A large correlation (0.410) was found between height and dairy character. Height was also highly correlated with final score and some of its component traits. This implies that large body size is scored higher for dairy character traits. Udder traits were not highly correlated, except for a 0.444 correlation between rear udder height and udder width. Among linearly scored traits, most correlations were below 0.3, in agreement with the findings of Thompson et al. (1983) and Lawstuen et al. (1987).

Genetic correlations were in most cases larger than phenotypic correlations. Most of the higher genetic correlations, indicating pleiotropic effects, were found between dairy character and udder width and rear udder height. The highest was the genetic correlation between breakdown conformation and dairy character trait and linear score for dairy character. As in other studies there was a relationship between udder traits, largest between udder width and rear udder height (0.686). However, the magnitude of genetic correlations obtained in our study, smaller than reported by Lawstuen et al. (1987), Norman et al. (1988) and Foster et al. (1989), might suggest some differences in the scoring system. An examination of the phenotypic and genetic correlations does not indicate that linearly scored traits could be effectively represented by a smaller number of traits.

\section{CONCLUSIONS}

Heritabilities of most of the linearly scored traits ranged from 0.14 to 0.30 . Similar magnitudes have been found by other authors. Genetic parameters were slightly lower than reported in the literature. Both heritabilities and genetic correlations indicate that reasonable progress through selection can be made. Further studies should provide information concerning the relationships between conformation traits and other important functional traits. 


\section{REFERENCES}

Ducrocq V., 1993. Genetic parameters for type traits in the French Holstein breed based on a multiple-trait animal model. Livest. Prod. Sci. 36, 143-156

Foster W.W., Freeman A.E., Berger P.J., Kuck A., 1989. Association of type traits scored linearly with production and herdlife of Holsteins. J. Dairy Sci. 72, 2651-2664

Funk D.C., Hansen L.B. , Funk D.A., 1991. Adjustment of linear type scores from Holsteins classifications for age and stage of lactation. J. Dairy Sci. 74, 645-650

Hayes A.E., Mao I.L., 1987. Effects of parity, age and stage of lactation at classification linear type scores of Holstein cattle. J. Dairy Sci. 70, 1898-1905

Lawstuen D.A., Hansen L.B., Johnson L.P., 1987. Inheritance and relationships of linear type traits for age groups of Holsteins. J. Dairy Sci. 70, 1027-1035

Lucas J.L., Pearson R.E., Vinson W.E., Johnson L.P., 1984. Experimental linear descriptive type classification. J. Dairy Sci. 67, 1767-1775

Misztal I., 1994. MTCAFS (MTC) - multitrait REML estimation of variance components program. Anonymous FTP site at num.ads.ugd.edu

Misztal I., Lawlor T.J., Short T.H., VanRaden P.M., 1992. Multiple-trait estimation of variance components of yield and type traits using an animal model. J. Dairy Sci. 75, 544-551

Norman H.D., Powell R.L., Wright J.R., Cassel B.G., 1988. Phenotypic and genetic relationship between linear functional type traits and milk yield for five breeds. J. Dairy Sci. 71, 1880-1896

Schaeffer G.B, Vinson W.E., Pearson R.E., Long R.G., 1985. Genetic and phenotypic relationships among type scored lineary in Holsteins. J. Dairy Sci. 68, 2984-2988

Short T.H., Lawlor T.J., 1992. Genetic parameters of conformation traits milk yield, and herd life in Holsteins. J. Dairy Sci. 75, 1987-1998

Thompson J.R., Lee K.L., Freeman A.E., Johanson L.P., 1983. Evaluation of a linearized type appraisal system for Holstein cattle. J. Dairy Sci. 66, 325-331

Żarnecki A., Jagusiak W., Trela J., Czaja H., 2000. Sire evaluation for type traits (in Polish). Research Institute of Animal Production and Central Animal Breeding Office. Kraków. 21, 63-70

\section{STRESZCZENIE}

\section{Parametry genetyczne ocenianych liniowo cech typu i budowy krów czarno-białych w Polsce}

Parametry genetyczne oszacowano na podstawie danych dotyczących liniowej oceny pokroju 87352 krów czarno-białych, przeprowadzonej w latach od 1995 do 2000. Liniowy system oceny typu i budowy krów obejmuje 15 cech punktowanych w skali od 1 do 9 punktów. Oprócz cech ocenianych liniowo uwzględniono pomiar wysokości w krzyżu oraz ocenę ogólną złożoną z sumy punktów uzyskanych dla 4 cech opisowych. Największą zmienność stwierdzono w cechach liniowych, wahającą się od $15,7 \%$ dla głębokości tułowia do $22,7 \%$ dla więzadła środkowego wymienia. Średnie oceny punktowe dla długości strzyków i ich ustawienia były znacznie niższe od punktacji umięśnienia, charakteru mlecznego i szerokości klatki piersiowej. Fenotypowe korelacje między cechami były, uogólniając, mniejsze od korelacji genetycznych. Najwyższą odziedziczalność oszacowano dla wysokości w krzyżu $(0,463)$. Cechy opisowe składające się na ocenę ogólną (kaliber 0,416, typ i budowa 0,291 ) charakteryzowały się umiarkowaną odziedziczalnością, nieco niższe były odziedziczalności oceny nóg i racic oraz wymienia. Odziedziczalności punktacji liniowych dla 9 cech mieściły się w granicach od 0,204 do 0,301 , dla 4 cech wahały się od 0,1 do 0,2 , a dla racic odziedziczalność wynosiła zaledwie 0,074 . Ocena ogólna była skorelowana z głębokością tułowia i szerokością klatki piersiowej. Niektóre z cech wymienia były genetycznie skorelowane między sobą, w szczególności zawieszenie tylne wymienia z szerokością wymienia, a więzadło środkowe wymienia z zawieszeniem tylnym i położeniem wymienia. Wielkości oszacowanych parametrów wskazują na możliwość genetycznego doskonalenia niektórych cech pokroju. 